їх отримувати навчальну інформацію з різноманітних джерел, формує в них навички самостійного планування й організації власного навчального процесу, що забезпечує перехід до неперервної освіти (самоосвіти) по завершенню навчання в інженернопедагогічному ВНЗ, надає змогу максимально використати сформовані позитивні якості особистості завдяки самостійному виборові часу і способів роботи, джерел інформації.

Отже, ми здійснили аналіз умов та передумов організації самостійної роботи майбутніх інженерів-педагогів у процесі вивчення педагогічних дисциплін. Але ця проблема, безперечно, не $є$ повністю дослідженою і потребує додаткових теоретичних та практичних наукових розвідок.

\title{
Література
}

1. Абдуллина О. А. Общепедагогическая подготовка учителя в системе высшего педагогического образования / О. А. Абдуллина. - [2-е изд., перераб. и доп.]- М. : Просвещение, 1990. - 141 с. 2. Забранський В. Я. Психолого-дидактичні передумови самостійної роботи студентів економічних спеціальностей 3 вищої математики/ В. Я. Забранський, Н. В. Вінніченко // Дидактика математики: проблеми і дослідження: міжнарод. збірник наук. робіт. - Донецьк: Вид-во ДонНУ, 2009. - Вип. 32. - С. 108-113. 3. Коваленко О. Е. Концепція професійно-педагогічної підготовки студентів інженерно-педагогічних спеціальностей / О. Е. Коваленко, Н. О. Брюханова, О. О. Мельниченко // Проблеми інженерно-педагогічної освіти. - Х., 2005. - Вип. 10. С. 7-20. 4. Фіногєєва Т. Є. Практичні питання розробки системи пізнавальних завдань для самостійної роботи студентів при вивченні психолого-педагогічних дисциплін/ Т. Є. Фіногєєва // Вісн. Луган. нац. пед. ун-ту імені Тараса Шевченка. - 2009. - № 9 (172) : Педагогічні науки. - С. 105-10. 5. Фіногєєва Т. С. Роль самостійної роботи у формуванні особистості майбутнього інженера-педагога / Т. С. Фіногєєва, О. А. Подураго, Н. О. Шипєльова // Інтеграція освіти, науки та виробництва у ХХІ столітті: матеріали XLII наук.-практ. конф. наук.-пед. працівників, науковців, асп., магістрів, студ. гірничого факультету УІПА. - Стаханов, 2009. - С. 64-69. 6. Фіногєєва Т. С. Особливості організації самостійної роботи студентів інженернопедагогічних спеціальностей 3 використанням системи пізнавальних завдань/ Т. Є. Фіногєєва // Вісн. Луган. нац. пед. ун-ту імені Тараса Шевченка. - Луганськ, 2009. - № 23 (186) : Педагогічні науки. Ч. 3 : За матеріалами IV міжнар. наук.-практ. конф. «Ціннісні пріоритети освіти ХХІ»: європейський вектор. - C. 112-122. 7. Фіногєєва Т. С. Самостійна робота в навчальному процесі вищих інженернопедагогічних навчальних закладах: сучасний стан та перспективи / Т. С. Фіногєєва// Педагогіка вищої та середньої школи : зб. наук. праць. - Кривий Ріг, 2012. - Вип. 36. С. 590-596. 8. Хуторской А. В. Дидактическая эвристика. Теория и технология креативного обучения / А. В. Хуторской. - М. : Изд-во МГУ, 2003. - 416 с.

УДК 378.009

Ганна Цвєткова

\section{СУТНІСНА ХАРАКТЕРИСТИКА ОСОБЛИВОСТЕЙ ПРОФЕСІЙНОГО САМОВДОСКОНАЛЕННЯ ВИКЛАДАЧІВ ГУМАНІТАРНИХ СПЕЦІАЛЬНОСТЕЙ}

Цвєткова Г. Г. Сутнісна характеристика особливостей професійного самовдосконалення викладачів гуманітарних спеціальностей.

У статті охарактеризовано сутнісні особливості самовдосконалення викладачів гуманітарних спеціальностей; зроблено порівняльний аналіз особливостей професійного самовдосконалення викладачів гуманітарних спеціальностей та вчителів 
загальноосвітньої школи, виокремлено причини успішності самовдосконалення викладачів гуманітарних спеціальностей.

Ключові слова: самовдосконалення, сутнісна характеристика особливостей самовдосконалення, детермінуюча цілемотиваційна спрямованість, саморефлексія, самоподолання через самообмеження, професійна самореалізація, професійна саморегуляція.

Цветкова А. Г. Сущностная характеристика профессионального самосовершенствования преподавателей гуманитарных специальностей.

В статье охарактеризованы сущностные особенности самосовершенствования преподавателей гуманитарных специальностей; осуществлен сравнительный анализ особенностей профессионального самосовершенствования преподавателей гуманитарных специальностей и учителей общеобразовательной школы; выделены причины успешности профессионального самосовершенствования преподавателей гуманитарных специальностей.

Ключевые слова: самосовершенствование, сущностная характеристика особенностей самосовершенствования, детерминирующая целемотивационная направленность, саморефлексия, самопреодоление через самоограничение, профессиональная самореализация, профессиональная саморегуляция.

Tsvetkova G. G. The modern characteristic of the professional improvement of teachers of humanitarian specialities.

The essential features of self-development of the teachers of humanitarian disciplines are characterized; a comparative analysis of the peculiarities of the professional improvement of the teachers of humanitarian disciplines and the teachers of comprehensive schools is made, the reasons for the success of self-development of teachers of humanitarian disciplines are distinguished in the article. It is proved that the formation of national motives of professional activity of a professional of the high school is a reflexive and changing process of reaching new horizons in the professional activities, assignment of the hierarchy of motives, values, affecting the development of a professional specialist.

Key words: self-perfection, characteristic features of self-improvement, determined purposeful-motivational orientation, self-reflection, self-denial, through self-restraint, professional self-realization, professional self-regulation.

Сучасний етап соціально-економічного й політичного розвитку суспільства, що характеризується мегадинамічністю й невпинними пошуками істинних буттєвих сенсів, вимагає відповідної зорієнтованості свідомості людини як істоти креативної, здатної до саморозвитку. Здійснюючи кожен наступний акт творення й самотворення, особистість повинна зіставляти відображення актуальної інформації з результатами минулих спроб $\mathrm{i}$, водночас, із потенціалами гіпотетичного майбутнього. Ця проблема набуває нового звучання, коли йдеться про особистість викладача вищої школи, який певною мірою забезпечує формування інтелектуального потенціалу нації, iї майбутнього.

У зв'язку з цим сучасний освітній процес має бути спрямований не лише й не стільки на формування необхідного мінімуму знань, умінь, навичок, скільки на розвиток здатності до самоосвіти й самовиховання. Саме ця здатність повинна бути важливим чинником розвитку духовної культури українського народу як основного першоджерела надій на відродження в інших галузях. Тому питання професійного самовдосконалення викладачів гуманітарних спеціальностей, з'ясування його сутнісних ознак, причин успішності набувають виняткової значущості. 
У напрямку аналізу самовдосконалення як частини духовності активно працюють українські науковці: І. Бех, М. Боришевський, І. Бужина, О.Вишневський, І. Зязюн, Н. Кордунова, І. Лебідь, К. Настояща, О. Пометун, Е. Помиткін, Н. Репа, В. Слюсаренко, О. Сухомлинська, Т. Тюріна, Г. Шевченко, Т. Шестакова.

Інтегративну сутність самовдосконалення та складники самоосвіти досліджують Ю. Калугін, Ю. Кулюткін, К. Левітан, І. Наумченко, К. Нефедова, В. Скнар, Г. Сєріков, П. Підкасистий, Г. Сухобська, А. Усова та ін.) й самовиховання (С. Слканов, О. Кучерявий, В. Кучинський, О. Лебедєв, К. Левітан, Л. Мнацаканян, Л. Рувінський, П. Семенов, 3. Сепчева, К. Тихончук, Д. Фельдгон, А. Яций).

Водночас визначення сутнісних ознак професійної діяльності викладача, його шляхів самовдосконалення залишається однією 3 нерозв'язаних проблем педагогіки вищої школи.

Мета статmі- охарактеризувати особливості самовдосконалення викладачів гуманітарних спеціальностей; порівняти особливості професійного самовдосконалення викладачів гуманітарних спеціальностей i вчителів загальноосвітньої школи, проаналізувати причини успішності самовдосконалення викладачів гуманітарних спеціальностей.

Змістова поліфункціональність, багатоаспектність професійно-педагогічної діяльності та самовдосконалення педагога вищої школи містить такі компоненти (за Є.Клімовим) [1]:

- цілісний - якості людини як цілого (образу світу, спрямованості, ставлення до зовнішнього світу; особливостей виявлення креативності, інтелектуальних та операторних рис індивідуальності, емоційності, професійних очікувань, уявлення про своє місце у професійній спільноті);

- праксис фахівця - (специфічні риси, прийоми інформації, іï перероблення i прийняття рішень, гностичні уміння, навички та діï);

- інформованість, знання - досвід, культура професіонала (специфічні риси, орієнтація в науковій галузі та теоретичні знання, професійні знання зі свого предмета);

- психодинамічний - (інтенсивність переживань, швидкість їхньої зміни, навантаження і труднощі в певній професійній галузі);

- усвідомлення своєї вікової і статевої належності відповідно до вимог професії.

Феномен самовдосконалення викладача вишу неможливо описати без звернення до структури його педагогічної діяльності. Відповідно до духовних орієнтирів самовдосконалення, грунтуючись на аналізі фундаментальних праць А. Деркача, Н. Кузьміної, В. Сластьоніна, О. Гури, виокремлюємо гностичну та рефлексивноперцептивну діяльність, що детермінується вміннями розв'язувати педагогічні задачі, намаганням самостійно здобувати знання, ініціативою в нестандартному баченні предмета педагогічної взаємодії; усвідомленням необхідності проникати викладачеві в індивідуальну своєрідність особистості студента та розуміти себе як професіонала й особистість; уміння виокремлювати пріоритети в професійній діяльності; проективну діяльність, пов'язану з наявністю системи професійних задач та проблемних ситуацій; володіння засобами та методами конструювання ситуації, впливом на неї; передбачування можливих результатів та поведінки студентів, створення креативної соціально-психологічної атмосфери у студентському колективі як засібу впливу на індивідуальність студента; організаційну діяльність, що визначається предметом соціально-педагогічної взаємодії, можливістю через студентський колектив впливати на окремі дії іншої людини (студента) та іiі поведінки загалом, звертатися до мотивів та цілей студента, але не перетворювати при цьому управління на маніпуляцію. Ця діяльність також характеризується вміннями аргументувати своє ставлення до 
професійної діяльності. Комунікативна діяльність виявляється у схильності отримувати максимальну інформацію в різноманітних iï виявах, відсутність страху перед суперечливою інформацією, що дозволяє мати чітке уявлення про проблемну ситуацію, скорегувати свою думку. Вищеозначена діяльність має всеохоплюючий характер, оскільки кожна лекція, семінарське заняття - спілкування викладача і студента на високому психолого-педагогічному рівні, що вимагає досягнення високого рівня розвитку професійних, комунікативних якостей, що складає фундамент та домінанту самовдосконалення викладача вишу.

Самовдосконалення викладача вишу - це не лише досягнення високих професійних результатів, висока продуктивність діяльності та технократичність праці. На нашу думку, на перший план висунуто мотиви професійного самовдосконалення, ціннісні орієнтації, внутрішні ресурси, задіяні в цьому неоднозначному процесі.

На основі теоретичного аналізу та власного досвіду визначимо сутнісні особливості самовдосконалення викладача вишу.

Професіонал вищої школи постає якістю суб'єкта, активного творця себе. Процеси саморозвитку, самовдосконалення зовнішньо спровоковані різноманітними обставинами, детермінуються внутрішніми потребами, духовною спрямованістю особистості та їі унікальною історією в межах вищого навчального закладу.

Сдність у механізмах самовдосконалення наукового та навчального, методичного та особистісного. Тільки гармонійне поєднання прагнень досконалості в означених ракурсах дає вихід викладачеві зі стану біфуркації, допомагає усвідомлювати нові необхідні компетенції як особистісні цілі, що свідомо конкретизуються та реалізуються в багатовимірній сумісній діяльності викладача і студента. При цьому технологічно має враховуватися не лінійність, притаманна процесам самовдосконалення фахівця. У педагогічній дійсності це відбувається у вигляді зміни станів відкритості та закритості особистісної системи, чергуванні упорядкованих та неупорядкованих періодів, зон плавного та різкого розвитку.

Спрямованість самовдосконалення викладача вишу не лише на себе, а й на розвиток студента, його креативно-самостійну роботу, активізацію навчальнопізнавальної діяльності, пробудження потреби в особистісному розвитку. Це здійснюється у враженні від дотику до особистості майстра для студентської аудиторії та забезпечує духовне прагнення викладача, разом із тим, орієнтуючи самовдосконалення професіонала вищої школи на цінності педагогічної спільноти та завдання модернізації вітчизняної вищої школи.

Особливості самовдосконалення професіонала вишу виявляються в розвиненому критичному педагогічному мисленні та самосвідомості особистості. Критичне педагогічне мислення- процес виявлення зовнішньо незаданих, прихованих рис педагогічної дійсності в результаті порівняння та класифікації ситуацій та винаходження в них причинно-наслідкових зв'язків (Д. Чернилевський) [2]. Водночас, професійне педагогічне мислення $є$ сукупністю пізнавальних прийомів та стратегій діяльності, що стають підгрунтям механізмів самовдосконалення викладача вишу та зумовлені особливостями педагогічної роботи. Професійне педагогічне мислення виявляється в межах виконання викладачем своїх професійних обов'язків та розповсюджується на особистісну сферу педагога. Однією 3 найвагоміших рис цього мислення є критичне, рефлексивне ставлення до себе як суб'єкта самовдосконалення. 3 іншого боку, толерантність щодо студентів та колег. Із цього ракурсу самовдосконалення відбувається на грунті багатократного мислєннєвого програвання педагогічної ситуації, конфлікту або суперечності, що виникнули в результаті діяльності та подальшого програвання й проектування шляхів розв'язання створеної ситуації. 
Разом із тим, толерантність як вияв високого ступеня саморозвитку та педагогічного стилю мислення передбачає спробу зрозуміти й обгрунтувати причини неадекватної, на перший погляд, поведінки студентів, колег. Толерантність виявляється в очікуванні поступового результату певного виховного впливу, визнання права людини на помилку.

Гуманістична спрямованість самовдосконалення викладача вишу, що виявляється в постійному розвиткові взаємодії, тандему «викладач - студент», у здатності викликати у студента шляхетні почуття. Бажання та намагання ставати кращим, досягати високих морально-професійних цілей, стимулювати студентів до самовдосконалення. Гуманістична спрямованість полягає в умінні викликати до себе повагу з боку студентської аудиторії, мати педагогічний авторитет.

Самодетермінованість самовдосконалення викладача вишу. Над професіоналом вищої школи ніхто не стоїть, тобто відсутня система жорсткого контролю з боку адміністрації вишу (іі взагалі намає), ніхто не вимагає вдосконалюватися. Мотиви самовдосконалення грунтуються на усвідомленій потребі, внутрішній необхідності, що переростає в постійну духовну та інтелектуальну працю особистості, без якої професіонал вищої школи не може існувати. Самодетермінованість самовдосконалення грунтується на базовій здатності професіонала самозмінюватися, самобудуватся, саморозвиватися в контексті культури. Тобто самопізнання, самоусвідомлення свого «я-реального» через колізійність самоподолання до самоствердження, самоактуалізацію та самотрансенденцію «Я-ідеального»- самодетермінований шлях професіонала ВНЗ до вершин професійного та духовного самовдосконалення, дотик до «печатки вічності», Істини, Добра, Краси. У цьому полягає нескінченність, незавершеність феномену досконалості.

Отже, особливість самовдосконалення викладача вишу визначається специфікою ціннісних орієнтацій, видами педагогічної діяльності, педагогічним критичним мисленням і педагогічними здібностями.

У сучасній педагогічній науці $\epsilon$ спроби автоматичного ототожнення діяльності викладача ВНЗ та шкільного вчителя, що пояснюється спільним видом діяльності. Зазначимо, що самовдосконалення викладача вишу, його професійна діяльність, грунтовно відрізняється від функцій, компонентів діяльності вчителя загальноосвітньої школи. Це так само відображається на сутнісних особливостях самовдосконалення викладача i вчителя загальноосвітньої школи. Порівняємо особливості самовдосконалення викладача вишу та вчителя загальноосвітньої школи (табл. 1).

Таблиця 1

Порівняльна характеристика самовдосконалення викладача вишу та вчителя загальноосвітньої школи

\begin{tabular}{|c|c|c|}
\hline Ознаки порівняння & $\begin{array}{l}\text { Специфіка } \\
\text { самовдосконалення } \\
\text { викладача вишу }\end{array}$ & $\begin{array}{l}\text { Специфіка самовдосконалення } \\
\text { вчителя } \\
\text { школи }\end{array}$ \\
\hline $\begin{array}{l}\text { 1. Мотивація } \\
\text { самовдосконалення }\end{array}$ & $\begin{array}{l}\text { Виражена внутрішньо } \\
\text { детермінована мотивація } \\
\text { до самовдосконалення, } \\
\text { значна роль } \\
\text { суб'єктивних факторів у } \\
\text { цьому процесі. }\end{array}$ & $\begin{array}{lr}\text { Більш } & \text { зовнішньо } \\
\text { детермінований } & \text { процес, } \\
\text { значну роль відіграють } \\
\text { зовнішні чинники. }\end{array}$ \\
\hline $\begin{array}{l}\text { 2. Механізми } \\
\text { самовдосконалення }\end{array}$ & $\begin{array}{lr}\text { Гармонійне } & \text { поєднання } \\
\text { наукового } & \text { та } \\
\text { навчального, } & \\
\text { методичного } & \text { та }\end{array}$ & $\begin{array}{lr}\text { Гармонійне } & \text { поєднання } \\
\text { викладацької, } & \text { виховної, } \\
\text { методичної, } & \text { управлінської } \\
\text { діяльності. } & \text { Акцент }\end{array}$ \\
\hline
\end{tabular}




\begin{tabular}{|c|c|c|}
\hline & $\begin{array}{l}\text { особистісного, акцент на } \\
\text { науково-дослідній } \\
\text { діяльності. }\end{array}$ & $\begin{array}{l}\text { викладацько-методичній } \\
\text { діяльності. }\end{array}$ \\
\hline $\begin{array}{l}\text { 3. Спрямованість } \\
\text { самовдосконалення }\end{array}$ & $\begin{array}{l}\text { Спрямованість на себе, } \\
\text { на взаємодію зі } \\
\text { студентом, на його } \\
\text { професійно-особистий } \\
\text { розвиток, креативно- } \\
\text { самостійну діяльність, } \\
\text { активізацію пізнавальної } \\
\text { діяльності. }\end{array}$ & $\begin{array}{l}\text { Спрямованість на себе, на } \\
\text { всебічний i гармонійний } \\
\text { розвиток дитини, на } \\
\begin{array}{l}\text { рефлексивне } \\
\text { діяльністю учнів. }\end{array}\end{array}$ \\
\hline $\begin{array}{l}\text { 4. Педагогічне } \\
\text { мислення як основа } \\
\text { самовдосконалення }\end{array}$ & $\begin{array}{l}\text { Критичне професійне } \\
\text { мислення, для якого } \\
\text { характерні: критичність, } \\
\text { дивергентність, } \\
\text { гнучкість, самостійність } \\
\text { суджень, проникливість, } \\
\text { спостережливість, } \\
\text { пізнавальна відкритість, } \\
\text { рефлексивне ставлення } \\
\text { до себе - толерантне до } \\
\text { колег та студентів. }\end{array}$ & $\begin{array}{l}\text { Рефлексивне ставлення до } \\
\text { себе - перцептивно-емпатійне } \\
\text { до дитини. }\end{array}$ \\
\hline $\begin{array}{l}\text { 5. Гуманістичнісь } \\
\text { самовдосконалення }\end{array}$ & $\begin{array}{l}\text { Виявляється в прагненні } \\
\text { самовдосконалення у } \\
\text { взаємодії в тандемі } \\
\text { «викладач-студент», } \\
\text { здатності до виховання } \\
\text { студентів, стимулюванні } \\
\text { іх до самовдосконалення }\end{array}$ & 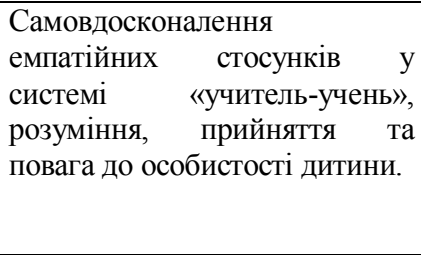 \\
\hline $\begin{array}{l}6 \text { Детермінованість } \\
\text { самовдосконалення }\end{array}$ & 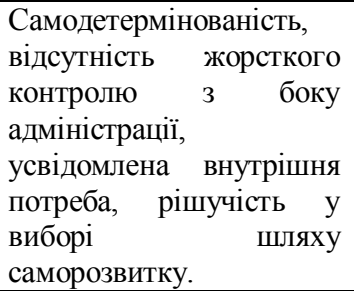 & 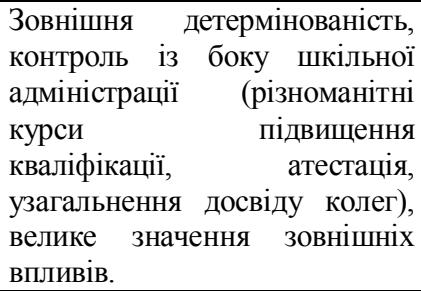 \\
\hline
\end{tabular}

Отже, порівняльний аналіз сутнісних особливостей самовдосконалення вчителів та викладачів свідчить про те, що особливості самовдосконалення означених професіоналів сугтєво відрізняються. Так, самовдосконалення викладачів вишів характеризується самодермінованістю в порівнянні з учителем загальноосвітньої школи, самовдосконалення якого детермінується ззовні. У вчителів загальноосвітньої школи акцент робиться на вдосконаленні викладацько-методичній діяльності, на відміну від викладача, у якого превалює орієнтація на науково-дослідну діяльність. Самовдосконалення аналізованих професіоналів відрізняється різною спрямованістю: у викладача на взаємодію зі студентом, на його професійно-особистісний розвиток, креативно-самостійну діяльність, активізацію пізнавальної діяльності; у вчителя на всебічний і гармонійний розвиток дитини, рефлексивне управління діяльністю учнів тощо. 
У ракурсі висвітлення проблеми неможливо не замислитися над питаннями: від чого залежить успішність, успіх самовдосконалення викладача вишу. Успіх самовдосконалення безпосередньо пов'язаний із готовністю професіонала відмовитися від попередніх намірів, досягнутих результатів, непродуктивних намагань. Чим рішуче викладач починає знову 3 «чистого листа» в плані досягнення самовдосконалення, попри дискомфорт (внутрішній, зовнішній), нестабільність здійснювати пошук нових рішень, тим інтенсивніше відбувається його саморозвиток.

За результатами проведеного опитування, у якому брали участь 300 викладачів вишів, у відповідь на питання, від яких чинників залежить успішність самовдосконалення професіонала ВНЗ, викладачі виокремили такі:

a) об'єктивні чинники - тип, структура та матеріально-технічні умови праці викладача - 27\%; морально-психологічний клімат на кафедрі - $20 \%$; стосунки 3 колегами - $17 \%$; пізнавальна діяльність студентів - 25\%;

б) суб'єктивні чинники: рівень мотивації самовдосконалення викладача - 45\%; рівень освіченості та педагогічної культури мислення - 65\%; рівень стресостійкості $77 \%$, емоційної рівноваги - 48\%; рівень фізичного здоров'я викладача - 99\%; продуктивна «Я-концепція», здатність до рефлексії- 43\%; орієнтація на гуманістичні цінності - 55\%; високий рівень креативності - $42 \%$; рівень професійних знань, умінь, навичок $-69 \%$.

Більше 70\% опитаних педагогів вищої школи зробили акцент на суб'єктивних чинниках успішності самовдосконалення. Це свідчить про усвідомлення професіоналами вищої школи значущості поставленої проблеми, відповідальності за свій професійно-педагогічний розвиток, достатній рівень розвиненої саморефлексії.

Перелік причин:

1. Тип, структура, матеріально-технічні умови праці.

2. Морально-психологічний клімат на кафедрі.

3. Стосунки з колегами.

4.Пізнавальна діяльність студентів.

5. Рівень мотивації самовдосконалення викладача.

6. Рівень освіченості та педагогічної культури мислення.

7. Рівень стресостійкості.

8. Емоційної рівноваги.

9. Рівень фізичного здоров'я викладача.

10. Продуктивна «Я-концепція», здатність до рефлексії.

11. Орієнтація на гуманістичні цінності.

12. Високий рівень креативності.

13. Рівень професійних знань, умінь, навичок.

Підкреслимо творчий характер процесів самовдосконалення 3 напруженим творчим пошуком, подоланням особистісної обмеженості, 3 інтуїтивними осяяннями, духовністю. Саме ці характерні особливості самовдосконалення - шлях до розв'язання складних, проблемних, іноді трагічних професійних та життєвих ситуацій.

У світлі сказаного, стає можливим визначити такі структурні елементи професійного самовдосконалення викладача вишу:

1) Детермінуюча цілемотиваційна спрямованість. Тобто, позитивна стійка психолого-педагогічна мотивація, особистісний інтерес викладача до продуктів індивідуального самовдосконалення, установка на самоактуалізацію, самореалізацію, досягнення професійного акме, високого рівня професійних компетенцій. У цій мотивації виявляється єдність позитивної внутрішньої мотивації до науково-дослідної, методичної, професійно-педагогічної та психолого-педагогічної діяльності. 


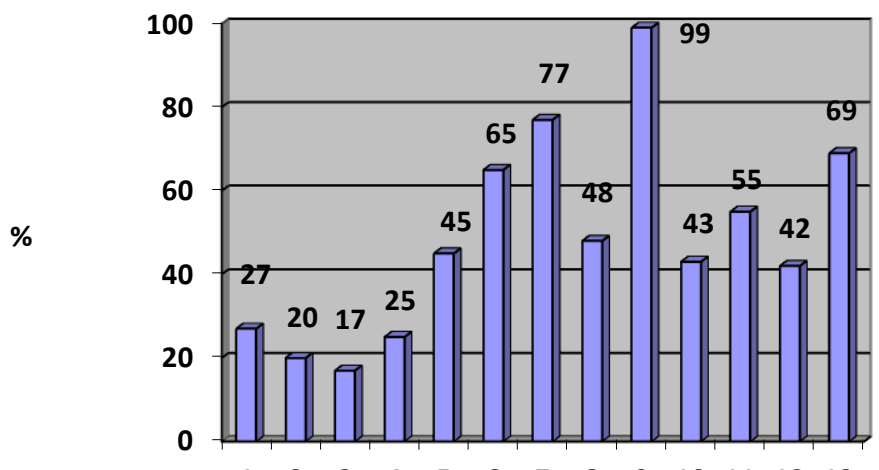

$\begin{array}{lllllllllllll}1 & 2 & 3 & 4 & 5 & 6 & 7 & 8 & 9 & 10 & 11 & 12 & 13\end{array}$

Рис.1. Аналіз причин успішності професійного самовдосконалення викладача вишу.

2) Саморефлексія, самопізнання. Самоусвідомлення на основі ціннісно-смислових уявлень змісту та результату самовдосконалення викладача, в яких превалюють гуманістична спрямованість, принциповість і толерантність формування продуктивної професійної Я-концепції та гідного ставлення до себе як до професіоналу.

3) Самоподолання через самообмеження, зменшення розриву між Я- професійнореальним та Я-ідеальним, усвідомлення та подолання суперечностейч на шляху досконалості.

4) Професійне самоствердження через самоактуалізацію, саморозкриття, розгортання індивідуальних професійних духовних сил педагога вищої школи.

5) Професійна самореалізація як набуття високого рівня компетентностей викладача, самопректування своєї педагогічної діяльності та взаємодія зі студентською аудиторією, реалізація педагогічних цілей, професійних мотивів, прогнозування ситуацій педагогічної взаємодії.

6) Самовдосконалення як усвідомлений процес професійної саморегуляції, самоконтролю, самокорекції, невпинний, нескінченний характер якого визначає нові вектори досконалості фахівця вищої школи, трансенденцію подальшого професійного та життєвого шляху.

Формування сенсостворювальних мотивів професійної діяльності професіонала вишу - рефлексивний, мінливий процес досягнення нових горизонтів у професійній діяльності, привласнення ієрархії мотивів-цінностей, що впливають на професійних розвиток фахівця. Педагогічна діяльність має полісемантичну природу, яка означає, що всі основні види мотивів та цінностей саморозвитку певною міроює в цій діяльності. Окреслено сутнісні особливості самовдосконалення викладача вишу, що полягають в активності суб'єкта (професіонала вищої школи) щодо самовдосконалення; у гармонійному синтезі механізмів самовдосконалення наукового й навчального, методичного та особистісного; спрямованості самовдосконалення викладача вишу на розвиток студента; у розвитку критичного педагогічного мислення; гуманістичній спрямованості та самодетермінованості викладача ВНЗ. Доведено, що процес самовдосконалення викладача вишу відображає логіку особистісного розвитку людини та має такі структурні елементи: детермінуючу цілемотиваційну спрямованість; саморефлексію, самопізнання; самоподолання через самообмеження; професійне 
самоствердження через самоактуалізацію; професійну самореалізацію; самовдосконалення як усвідомлений процес професійної саморегуляції.

\section{Література}

1. Климов Е. А. Педагогический труд : психологические составляющие / А. Климов. - М. : Изд. центр «Академия», 2004. - 240 с. 2. Морозов А.В. Креативная педагогика и психология: [учебное пособие]/ Александр Владимирович Морозов, Дмитрий Владимирович Чернилевский. - [2-е изд., испр. и доп.] - М. : Академический Проект, 2004. -- 560 с.

УДК [378+62]:372.874.1

Людмила Цвіркун

\section{РОЗВИТОК ПРОЕКТНО-КОНСТРУКТОРСЬКОЇ КОМПЕТЕНТНОСТІ СТУДЕНТІВ У ПРОЦЕСІ ГРАФІЧНОЇ ПІДГОТОВКИ}

Цвіркун Л. О. Розвиток проектно-конструкторської компетентності студентів у процесі графічної підготовки.

У статті розглянуто наукові поняття «графічна грамотність», «графічна компетентність», «графічна професійна компетентність», «проектно-конструкторська компетентність», уточнено сутність використовуваних понять у процесі графічної підготовки студентів, конкретизовано терміни та сконцентровано увагу на важливості розвитку проектно-конструкторської компетентності студентів у процесі вивчення графічних дисциплін.

Ключові слова: графічна грамотність, графічна компетентність, графічна професійна компетентність, проектно-конструкторська компетентність.

Цвиркун Л. А. Развитие проектно-конструкторской компетентности студентов в процессе графической подготовки.

В статье рассмотрены научные понятия «графическая грамотность», «графическая компетентность», «графическая профессиональная компетентность», «проектноконструкторская компетентность», уточнена суть используемых понятий в процессе графической подготовки студентов, конкретизированы термины и сконцентрировано внимание на важности развития проектно-конструкторской компетентности студентов в процессе изучения графических дисциплин.

Ключевые слова: графическая грамотность, графическая компетентность, графическая профессиональная компетентность, проектно-конструкторская компетентность.

Tsvirkun L. O. The development of design competence of students in the graphic preparation.

The article deals with the scientific concept of «graphic literacy», «graphic competence», «graphics professional competence», «design and engineering expertise», clarifies the nature of the concepts in the image of students, specifies the terms and focuses on the importance of the development of design competence of students in the study of graphic disciplines.

Key words: graphic literacy, graphical competence, graphics professional competence, design and engineering expertise.

Графічна підготовка студентів посідає важливе місце у процесі вивчення графічних дисциплін, оскільки є невід'ємним складником вищої технічної освіти 